\title{
Komunikasi Cyber CSR: Analisis Isi pada Official Website PT Bank Pembangunan Daerah Jawa Barat dan Banten
}

\author{
Oleh \\ Dedi Kurnia Syah Putra, ${ }^{1}$ dan Nisa Dwi Saputri, ${ }^{2}$ \\ ${ }^{1}$ Pengajar Tetap Ilmu Komunikasi, Fakutas Komunikasi dan Bisnis, Universitas Telkom, Bandung. \\ E-mail: dedikurniasp@ elkomuniversity.ac.id, \\ ${ }^{2}$ Peneliti muda pada Pusat Penelitian, The Centre for Media Gender and Democracy
}

\begin{abstract}
Abstrak
Komunikasi CSR adalah proses mengantisipasi harapan stakeholders, artikulasi terhadap kebijakan CSR, dan menata berbagai media komunikasi perusahaan untuk mengelola informasi CSR yang benar dan transparan (Podnar dalam Nwagbara dan Reid, 2013: 409-410). Di era digital, official Website merupakan salah satu media komunikasi yang banyak digunakan oleh perusahaan untuk mengkomunikasikan CSR. PT Bank Pembangunan Daerah Jawa Barat \& Banten Tbk merupakan bank emiten yang mengkomunikasikan CSR dengan mengalokasikan menu khusus CSR pada official Website. Tujuan dari penelitian ini adalah mendeskripsikan komunikasi cyber CSR yang dilakukan oleh Bank BJB pada official Website. Penelitian ini menelaah analisis isi pesan CSR, penyajian informasi CSR, dan pola komunikasi CSR pada official Website perusahaan. Penelitian ini menggunakan metode analisis isi untuk menganalisis teks yang memuat informasi CSR Bank BJB pada official Website, analisis teks dilakukan dengan menggunakan teknik studi dokumentasi untuk mengumpulkan data yang sesuai dengan tujuan penelitian, yakni menemukan knsep utama terkait pola komunikasi CSR Bank BJB dengan pendekatan model public information, komunikasi CSR Bank BJB pada official webite bersifat one asymmetrical communication, sebagaimana official Website hanya didominasi oleh perusahaan.
\end{abstract}

Kata kunci: Komunikasi Cyber CSR, Informasi Publik CSR, Analisis Isi CSR, Two Asymetrical Communication.

\section{A. Pendahuluan: Reputasi sebagai Aset Keberlanjutan}

Reputasi korporat akan memberikan implikasi strategis bagi perusahaan, sehingga pengelolaan reputasi merupakan salah satu keunggulan kompetitif dunia bisnis. Shamma dalam jurnalnya yang berjudul "Toward a Comprehensive Understanding of Corporate Reputation: Concept, Measurement and Implications" (2012: 151), mendefinisikan reputasi perusahaan sebagai aset strategis yang sangat berharga bagi perusahaan, aset tersebut untuk mempertahankan keberlanjutan hidup perusahaan dalam hubungan jangka panjang dengan beberapa kelompok stakeholders.

Dalam membangun reputasi, perusahaan semakin menyadari tidak hanya memenuhi tuntutan dari shareholder yaitu memaksimalkan pencapaian profit semata dan good performance, namun juga harus memenuhi harapan-harapan stakeholders yaitu memiliki kepedulian terhadap kelestarian lingkungan dan kesejahteraan masyarakat. Perusahaan seolah-olah dituntut oleh stakeholders untuk menyeimbangkan 3P (people, 
profit, planet) sebagai tanggung jawab terhadap dampak operasional perusahaandan upaya bertahan hidup dalam rentang waktu yang panjang.

Sejalan dengan pergeseran orientasi tersebut, lahir sebuah konsep yang sudah lama dipraktikkan di luar negeri namun tergolong baru dilakukan oleh perusahaan di Indonesia yakni tanggung jawab sosial perusahaan (Corporate Social Responsibility/CSR). Pelaksanaan tanggung jawab sosial perusahaan di Indonesia telah diatur oleh Undang Undang No. 40 tahun 2007 tentang perseroan terbatas. Undang-Undang tersebut mewajibkan setiap perusahaan, termasuk Badan Usaha Milik Negara (BUMN) yang berbentuk persero, untuk melaksanakan kegiatan CSR selama masih beroperasi.

CSR merupakan salah satu bentuk implementasi dari konsep tata kelola perusahaan yang baik. Para stakeholders menempatkan harapan yang tinggi untuk keberlangsungan hidup perusahaan dengan melaksanakan CSR. Butterick dalam bukunya yang berjudul Pengantar Public Relations: Teori dan Praktik (2012: 95), menjelaskan bahwa perusahaan dapat meningkatkan reputasi dengan melaksanakan praktik CSR yang didasari dari harapan stakeholders-nya.Oleh karena itu, setiap perusahaan perlu memberi perhatian khusus terhadap pelaksanaan CSR sesuai dengan tuntutan stakeholders.

Upaya untuk membangun reputasi dengan melaksanakan CSR akan menjadi siasia jika stakeholders tidak mengetahui dan tidak menyadari bahwa perusahaan telah mengimplementasikan CSR dengan baik. Oleh karena itu, perusahaan harus memberikan informasi melalui saluran komunikasi CSRkepada stakeholders secara efektif. Komunikasi CSR memiliki kekuatan untuk membentuk reputasi berdasarkan interpretasikan program.

Selain itu, komunikasi CSR berpeluang untuk menjaring masukan dari stakeholders melalui two assymetrical merupakan pilar utama untuk menjaga keberlangsungan operasional perusahaan dalam jangka waktu yang panjang. Dengan demikian, komunikasi CSR menjadi bagian penting yang harus dikelola oleh perusahaan sebagai salah satu kunci keberhasilan pelaksanaan CSR dalam mempertahankan reputasi.

Harmoni (2014) dalam paperyang berjudul "Media Richness Theory dan Potensi Website sebagai Media Komunikasi CSR oleh Perusahaan" mendefinisikan komunikasi CSR sebagai komunikasi yang dirancang dan didistribusikan oleh perusahaan tentang kegiatan CSR-nya. Dari definisi tersebut dapat dipahami bahwa perusahaan dituntut untuk fokus merancang pesan CSR yang tepat dan sesuai dengan stakeholders yang dituju, perusahaan juga harus mempertimbangkan pendistribusian pesan CSR dengan berbagai saluran komunikasi CSR yang akan digunakan oleh perusahaan untuk mencapai reputasi yang baik.

Nwagbara dan Reid dalam jurnalnya yang berjudul "Corporate Social Responsibility Communication in the Age of New Media: Towards the Logic of Sustainability Communication" (2013: 401) sebagaimana mengutip definisi komunikasi CSR menurut Podnar sebagai proses mengantisipasi harapan dari stakeholders, dan mengelola alat komunikasi yang dimiliki perusahaan dengan menyediakan informasi yang benar serta lebih transparan mengenai perusahaan dalam operasi bisnis, sosial, dan lingkungan, serta interaksi dengan stakeholders. Transparan merupakan nilai yang paling utama dalam komunikasi CSR.

Dewasa ini perusahaan dianjurkan untuk mengkomunikasikan CSR secara relevan dan transparansi sesuai dengan standar yang mengacu pada prinsip keberlanjutan. Global 
Diterbitkan oleh Program Studi IImu Komunikasi

Universitas Ahmad Dahlan Yogyakarta

Reporting Initiative (GRI) merupakan standar komunikasi CSR mutakhir yang banyak digunakan oleh perusahaan internasional dan di dalamnya terdapat aspek-aspek yang perlu dikomunikasikan mengacu pada prinsip keberlanjutan sesuai dengan standar ISO 26000.

Jurnal ini secara khusus membedah praktik komunikasi CSR secara siber, yakni penggunaan ruang official Website perusahaan untuk mengkomunikasikan program CSR. Perkembangan teknologi di era globalisasi saat ini secara tidak langsung telah mempengaruhi segala aspek, termasuk cara kerja perusahaan dalam komunikasi CSR. Eksistensi penggunaan media sibersebagai alat komunikasi antara komunikator dan komunikan melalui teknologi Internet terus mengalami peningkatan setiap harinya, hal ini menjadikan tantangan baru bagi perusahaan dalam menginovasi media komunikasi CSR perusahaan.

Website adalah salah satu media komunikasi CSR terpopuler yang telah digunakan oleh perusahaan sebagai alat penting untuk mengkomunikasikan CSR. Penggunaan Website perusahaan dalam mengkomunikasikan CSR mampu membidik kelompok stakeholders yang lebih luas, dapat mempublikasi informasi CSR lebih banyak dengan biaya yang tidak mahal, dan kemudahan memperoleh umpan balik dari para stakeholders.

Berdasarkan permasalahan ini, jurnal ini berupaya untuk menjelaskan isi pesan CSR yang dikomunikasikan oleh Bank BJB melalui official Website. Selain itu, penelitian ini akan mengkaji mengenai bentuk penyajian informasi dalam menyampaikan isi pesan CSR tersebut dan pola komunikasi CSR pada official Website Bank BJB.

\section{B. Tinjauan Literatur Penelitian}

\section{Corporate Social Responsibility}

Corporate Social Responsibility (CSR) merupakan suatu elemen penting dalam kerangka sustainability, yang mencakup aspek ekonomi, lingkungan dan sosial budaya. Rusdianto dalam bukunya yang berjudul CSR Communications A Framework for PR Practitioners (2013: 2) menjelaskan bahwa konsep CSR pertama kali muncul dalam wacana akademik sejak Howard R Bowen menerbitkan bukunya yang berjudul Social Responsibilitity of the Businessman pada tahun 1953. Ide dasar CSR yang dikemukakan Bowen mengacu pada kewajiban pelaku bisnis untuk menjalankan usahanya sejalan dengan nilai-nilai dan tujuan yang hendak dicapai masyarakat di tempat perusahaannya beroperasi.

Istilah CSR di Indonesia semakin terkenal dan populer digunakan sejak tahun 1990-an. Beberapa perusahaan, sebenarnya telah lama melakukan Corporate Social Activity (CSA) atau "aktivitas sosial perusahaan", walaupun tidak menamainya dengan sebutan CSR, secara faktual aksinya mendekati konsep CSR yang mempresentasikan bentuk "peran serta" dan "kepedulian" perusahaan terhadap aspek sosial dan lingkungan.

Untung dalam bukunya yang berjudul Corporate Social Responsibility (2008: 9-

15) menjelaskan bahwa tujuan dari CSR adalah untuk pemberdayaan masyarakat dan bukan memperdayai masyarakat. Pemberdayaan bertujuan untuk mengkreasikan masyarakat mandiri, kalau berbicara tentang CSR, terdapat banyak definisi. Kata sosial 
sering diinterpretasikan dengan kedermawanan. Padahal CSR terkait dengan sustainability dan acceptability, artinya diterima dan berkelanjutan untuk berusaha di suatu tempat.

Secara sederhana CSR didefinisikan sebagai kewajiban sosial suatu organisasi kepada masyarakat. Rachman et al. (2011: 17) dalam bukunya yang berjudul Panduan Lengkap Perencanaan CSR sebagaimana mengutip definisi yang dipaparkan oleh ISO 26000 sebagai:

"CSR is responsibility of an organization or the impact of its decission and activities on society and the environment, through transparant and ethical behaviour that contributes to sustainable development, health and the welfare of society, takes into account the expectations of stakeholders, is in compliance with applicable law and consistent with international norms of behaviour, and is integrated throughout the organization and practiced in its relationship".

ISO 26000 mengartikan CSR sebagai bentuk tanggung jawab perusahaan atas dampak dari keputusannya dan aktivitas perusahaan terhadap masyarakat dan lingkungan, melalui perilaku transparan dan etis, dengan konsisten memberikan kontribusi untuk pembangunan berkelanjutan dan kesejahteraan masyarakat, memperhatikan harapan dari stakeholders, sesuai dengan hukum yang berlaku serta konsisten dengan norma-norma internasional dalam bertindak, yang terintegrasi pada seluruh kegiatan perusahaan. Secara sederhana definisi di atas dipahami sebagai tanggung jawab suatu organisasi yang atas dampak dari keputusan dan aktivitasnya terhadap masyarakat dan lingkungan, melalui perilaku yang transparan dan etis. Hal ini semua akan berdampak pada kontribusi perusahaan dalam mewujudkan pembangunan berkelanjutan.

Selain definisi yang dipaparkan oleh ISO 26000, Nurjaman dan Umam dalam bukunya yang berjudul Komunikasi Public Relation (2012: 127) sebagaimana mengutip definisi CSR menurut Irianta yaitu, CSR adalah tanggung jawab perusahaan untuk menyesuaikan diri terhadap kebutuhan dan harapan stakeholders yang berkaitan dengan isu-isu etika, sosial, dan lingkungan, di samping ekonomi. Definisi tersebut menegaskan dalam setiap keputusan dan tindakan yang dilakukan oleh perusahaan haruslah mengintegrasikan harapan stakeholders terkait sosial dan lingkungan ke dalam operasi perusahaan dan interaksinya dengan stakeholders. Perusahaan harus mengingat bahwa perusahaan dikelilingi oleh stakeholders yang beragam dan stakeholders tersebut selalu berdampak pada keputusan dan tindakan operasi perusahaan.

Definisi CSR juga dipaparkan oleh Commission of Eropean Communities sebagaimana dikutip oleh Nguyen dan Wall dalam penelitiannya yang berjudul "An analysis of CSR online communication (The case of Shell, ExxonMobil, E.ON, and Vestas)" (2010: 13) yang menyatakan CSR sebagai "A concept whereby companies integrate social and environmental concerns in their business operations and in their interaction with their stakeholders on a voluntary basis." Definisi CSR di atas diartikan sebagai konsep dimana perusahaan mengintegrasikan masalah sosial dan lingkungan dalam operasi bisnis mereka dan interaksi dengan para stakeholders secara sukarela.

Dapat dipahami bahwa CSR sebagai Inisiatif perusahaan dengan tindakan sukarela sebagaimana bentuk tanggung jawab atas dampak yang ditimbulkan dari kegiatan 
Diterbitkan oleh Program Studi IImu Komunikasi

Universitas Ahmad Dahlan Yogyakarta

operasional perusahaan, namun tetap berorientasi pada keuntungan ekonomi dengan mempertimbangkan hubungan sosial dan faktor lingkungan.

Rachman et al. (2011: 15) menjelaskan konsep CSR menurut lingkar studi CSR Indonesia sebagai upaya sungguh-sungguh dari entitas bisnis untuk meminimalkan dampak negatif dan memaksimalkan dampak positif yang bermanfaat di masa yang akan datang operasinya terhadap seluruh pemangku kepentingan dalam ranah ekonomi, sosial, dan lingkungan agar mencapai tujuan keberlanjutan.

Dari definisi-definisi di atas dapat disimpulkan bahwa CSR merupakan komitmen dan upaya perusahaan sebagai bentuk pertanggungjawaban untuk meningkatkan kualitas hidup stakeholders. Kepeduliaan sosial perusahaan terutama didasari alasan bahwa kegiatan perusahaan membawa dampak (for better or worse), bagi kondisi lingkungan dan sosial-ekonomi masyarakat, khususnya di sekitar perusahaan beroperasi. Perusahaan tidak hanya melakukan tanggung jawab terhadap dampak dari kegiatan operasi tapi perusahaan juga mempunyai kekuatan yang besar untuk merubah ekonomi, lingkungan, dan sosial secara mendunia dengan cara meminimalkan resiko dan memaksimalkan manfaat bagi stakeholders. Selain itu, pemilik perusahaan sejatinya bukan hanya shareholders atau para pemegang saham. Melainkan pula stakeholders, yakni pihak-pihak yang berkepentingan terhadap eksistensi perusahaan.

CSR menjadi sebuah kewajiban baru dalam standar bisnis yang harus dipenuhi oleh perusahaan untuk keberlanjutan hidup perusahaan dalam rentang waktu yang panjang dengan menyeimbangkan 3P (profit, people, profit). Rusdianto (2013: 8) memaparkan pendapat Carrol bahwa CSR merupakan bentuk kepedulian perusahaan yang harus didasari dari perspektif tiga prinsip dasar yang lebih dikenal sebagai triple bottom lines, dijelaskan sebagai berikut:

1. Profit. Profit merupakan unsur terpenting dan menjadi tujuan utama dari setiap kegiatan usaha, Perusahaan harus tetap berorientasi untuk mencari profit agar perusahaan terus beroperasi dan berkembang.

2. People. Kegiatan operasional perusahaan berpotensi memberikan dampak kepada, perusahaan harus memiliki kepedulian terhadap kesejahteraan manusia, perusahaan perlu berkomitmen untuk berupaya memberikan manfaat sebesar-besarnya kepada mereka.

3. Profit. Lingkungan adalah sesuatu yang terikat dengan seluruh bidang kehidupan, Lingkungan dapat menjadi teman atau musuh, tergantung bagaimana memperlakukannya. Oleh karena itu, perusahaan penting mempunyai sikap peduli terhadap lingkungan hidup dan keberlanjutan keanekaragaman hayati.

Rachman et al. (2011: 39) menjelaskan bahwa saat ini pada tatanan internasional telah disusun suatu pedoman tanggungjawab sosial, termasuk bagi implementasi CSR, International Organization for Standardization (ISO) merupakan organisasi standarisasi internasional yang mengintegrasikan panduan dan standardisasi untuk tanggung jawab sosial pada bulan September tahun 2004, yang diberi nama ISO 26000: Guidance Standard on Social Responsibility. ISO 26000 merupakan standar pedoman untuk implementasi CSR. Dalam draft ISO 26000 terdapat tujuh isu utama CSR seperti disajikan pada gambar berikut: 


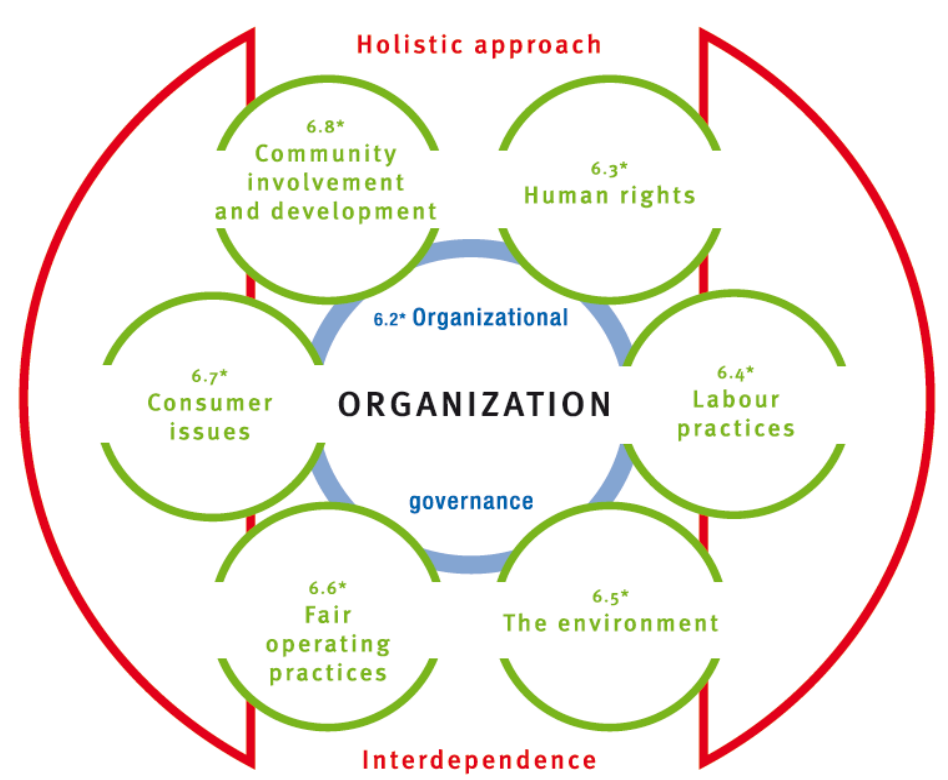

Sumber dikutip dari laman www.iso.org untuk komitmen CSR

Nguyen dan Wall (2010: 13) menjelaskan bahwa CSR telah menjadi isu penting dalam manajemen bisnis sebuah perusahaan, karena CSR dapat berkontribusi terhadap citra dan reputasi perusahaan. Dapat dipahami bahwa CSR merupakan langkah awal perusahaan untuk membangun dan menjaga reputasi perusahaan, dengan dampak positif yang dihasilkan dari pelaksanaan CSR tersebut yaitu baik bagi pihak-pihak yang terkait secara langsung maupun tidak langsung, antara lain bagi perusahaan itu sendiri, masyarakat dan juga pemerintah. CSR akan menjadi strategi bisnis yang mutlak dalam perusahaan untuk menjaga atau meningkatkan daya saing melalui reputasi.

\section{Mendefinisikan Komunikasi CSR}

Berbicara mengenai komunikasi CSR, setiap perusahaan yang melaksanakan CSR dituntut untuk memiliki pemahaman komunikasi CSR yang efektif kepada stakeholders perusahaan. Fungsi komunikasi menjadi hal utama dalam manajemen CSR. Sebagian para ahli dan peneliti telah memaparkan definisi dari komunikasi CSR. Podnar dalam Nwagbara dan Reid (2013: 409-410) mendefinisikan komunikasi CSR sebagai:

“CSR communication is a process of anticipating stakeholders' expectations, articulation of CSR policy and managing of different organisations communication tools designed to provide true and transparent information about a company's or brand's integration of its business operations, social and environmental concerns, and interactions with stakeholders."

Podnar mengartikan komunikasi CSR sebagai proses mengantisipasi harapan stakeholders, mengartikulasikan kebijakan CSR, dan mengelola alat komunikasi yang dimiliki perusahaan, dengan menyediakan informasi yang benar dan transparan mengenai 
Diterbitkan oleh Program Studi IImu Komunikasi

Universitas Ahmad Dahlan Yogyakarta

perusahaan dalam operasi bisnis, sosial, dan perhatian lingkungan, serta interaksi dengan stakeholders.

Definisi selanjutnya dipaparkan oleh Jalal dalam Rusdianto (2013: 21) bahwa komunikasi CSR sebagai upaya perusahaan dalam menyampaikan pesan kepada stakeholders dan menerima pesan dari stakeholders terkait komitmen, kebijakan, program dan kinerja perusahaan dalam pilar ekonomi, lingkungan, dan sosial.

Dapat dipahami dari definisi-definisi di atas bahwa komunikasi CSR tidak terlepas dari kritikan yang dievaluasi oleh stakeholders dan harus dihadapi oleh perusahaan. Dalam proses komunikasi CSR tidak hanya perusahaan yang menyampaikan pesan, tetapi baik perusahaan maupun stakeholders saling menyampaikan dan menerima pesan untuk mencapai kesepakatan bersama. Selain berbicara mengenai isi pesan dan mengelola media komunikasi yang digunakan dalam komunikasi CSR, perusahaan juga dituntut untuk menyampaikan informasi terkait kinerja perusahaan dalam fokus lingkungan, ekonomi, dan sosial-budaya secara akuntabilitas dan transparan agar mendapatkan kepercayaan dari stakeholders yang berdampak pada reputasi perusahaan.

Harmoni dalam jurnalnya yang berjudul "Interaktivitas Isu CSR Pada Laman Resmi perusahaan Studi Pada PT Indocement Tunggal Prakarsa Tbk" (2009: B58) menjelaskan bahwa dalam komunikasi CSR yang baik, perusahaan dituntut untuk mengkomunikasikan komitmen dan membangun kesadaran perusahaan, mengidentifikasi adanya resiko dan kesempatan, menuju peningkatan yang berkelanjutan, mendukung moral, melindungi/meningkatkan reputasi dengan melibatkan stakeholders dalam proses komunikasi CSR yang dilakukan. Jika perusahaan hendak mendapatkan kepercayaan dan legitimasi melalui pelaksanaan CSR, maka perusahaan harus membangun komunikasi CSR dengan melibatkan stakeholders, seperti mendengarkan informasi apa yang dibutuhkan oleh mereka.

Komunikasi CSR merupakan faktor utama untuk membangun reputasi perusahaan. Dowling dalam Butterick (2012: 58) mendefinisikan reputasi perusahaan sebagai "hasil penilaian" yang menggambarkan citra perusahaan berdasarkan pandangan masyarakat.

Rusdianto (2013: 89) menjelaskan bahwa komunikasi CSR dapat dimanfaatkan oleh perusahaan untuk membangun reputasi. Perusahaan yang sadar akan pentingnya keberadaan stakeholders, maka akan mengelola komunikasi CSR yang efektif dengan stakeholders-nya. Dalam membangun, mengembangkan, dan meningkatkan reputasi berdasarkan pandangan stakeholders, perusahaan dituntut mengelola kemampuan berkomunikasi. Reputasi merupakan pendekatan komunikasi agar perusahaan terhindar dari krisis. Oleh karena itu, komunikasi CSR harus terencana, terarah, dan dijalankan secara keberlanjutan kepada stakeholders, agar tercipta sebuah reputasi perusahaan.

\section{Media Komunikasi CSR}

Nwagbara dan Reid (2013: 407) menjelaskan bahwa organisasi dapat mengelola reputasi melalui komunikasi CSR di berbagai saluran komunikasi yang dapat dibaca, dipahami, dan diinterpretasikan oleh para stakeholders terkait keberlanjutan perusahaan. Agar pesan CSR dapat diterima secara efektif oleh stakeholders penting bagi perusahaan untuk mengelola berbagai alat komunikasi perusahaan. Strategi dalam mengelola media 
komunikasi CSR perusahaan merupakan bagian terpenting untuk membangun hubungan antara perusahaan dengan stakeholders-nya.

Di indonesia, kewajiban perusahaan untuk melakukan komunikasi CSR telah diatur dalam UU No.40 Tahun 2007 pasal 66 ayat (2) tentang perseroan terbatas. Dalam peraturan tersebut disebut bahwa perusahaan yang mengelola sumber daya alam diwajibkan untuk mengkomunikasikan aktivitas CSR-nya melalui media laporan tahunan.

Rusdianto (2013: 57) menjelaskan bahwa banyak media yang dapat dipilih perusahaan dalam komunikasi CSR, yaitu: media yang bersifat internal (Public Relation, Laporan CSR, majalah internal, website, media sosial dan lainnya) dan media yang bersifat eksternal (media massa, dan word of mouth).

Di era komunikasi multi channel, banyak media yang dapat digunakan oleh perusahaan untuk mengkomunikasikan CSR-nya. Pertama, laporan tahunan (annual report) adalah media komunikasi utama perusahaan untuk menyebarkan informasi tentang posisi keuangan perusahaan. Laporan tahunan ini kemudian secara ekstensif juga digunakan untuk mengomunikasikan informasi lingkungan.

Kedua, media lain yang semakin populer digunakan adalah laporan CSR atau laporan keberlanjutan (sustainability report) yang tersendiri. Namun tidak hanya annual report dan sustainability report sebagai media komunikasi CSR, menurut studi empiris yang dilakukan CSR Europe ada beberapa cara lain untuk mengomunikasikan CSR, yaitu: laporan sosial (social report), laporan tematik (thematic report), codes of conduct, web (websites), konsultasi stakeholders, komunikasi internal, pemberian hadiah, cause-related marketing, komunikasi pada kemasan produk, intervensi pada media dan TV, dan komunikasi pada pusat penjualan.

GRI menjelaskan bahwa komunikasi melalui media elektronik yaitu website dan media komunikasi konvensional merupakan media komunikasi CSR yang sesuai untuk pelaporan CSR perusahaan. GRI menganjurkan perusahaan dapat memilih untuk mengkombinasikan media komunikasi elektronik yaitu website dan media konvensional yaitu sustainability report atau hanya menggunakan salah satu media saja. Pemilihan media komunikasi (website atau konvensional) sebagai alat komunikasi CSR perusahaan harus memberikan akses kepada stakeholders dengan informasi CSR yang lengkap untuk periode pelaporan tersebut (GRI G4, 2014: 8).

Perusahaan yang mempertahankan praktek bisnis yang berkelanjutan, harus secara serius mengambil peluang yang ditawarkan oleh new media yaitu media komunikasi CSR melalui Website. Website memenuhi kriteria sebagai pelengkap komunikasi CSR melalui media tercetak yang efektif di tengah-tengah tuntutan kebutuhan informasi stakeholders yang beragam sifatnya dan segera tersedia (Nwagbara dan Reid, 2013: 411).

Dapat dipahami bahwa media komunikasi CSR perusahaan tidak hanya melalui laporan tahunan tetapi dapat melalui berbagai macam media komunikasi lain dengan mengikuti konvergensi media komunikasi, hal tersebut diungkapkan sebagai bentuk komitmen perusahaan kepada para stakeholders secara transaparan dan keberlanjutan. Di era new media berbagai studi yang dilakukan menunjukkan banyak cara yang dipilih oleh perusahaan untuk mengkomunikasikan CSR-nya dengan media elektronik yaitu official website perusahaan. Sebuah langkah dalam penyampaian informasi CSR melalui media internet yaitu official wesbite disebut sebagai komunikasi cyber CSR. 
Diterbitkan oleh Program Studi IImu Komunikasi

Universitas Ahmad Dahlan Yogyakarta

\section{Komunikasi Cyber CSR}

Cyber CSR adalah inisiatif sebagai cara atau strategi kerja perusahaan khususnya dalam bidang CSR dengan menggunakan media internet sebagai sarana publisitasnya. Diadaptasi dari Definisi cyber PR menurut Hidayat dalam bukunya yang berjudul Media Public Relations (2014: 95), cyber CSR didefinisikan sebagai strategi komunikasi perusahaan dalam penyampaian informasi terkait CSR perusahaan kepada stakeholders melalui teknologi on-line internet.

Mengadopsi dari definisi-definisi komunikasi CSR dan terkait cyber CSR, dapat disimpulkan bahwa definisi komunikasi cyber CSR adalah upaya perusahaan dalam menyampaikan pesan dan mendistribusikan pesan yang telah dirancang terkait komitmen, kebijakan, program dan kinerja perusahaan dalam pilar ekonomi, lingkungan, serta sosial kepada para stakeholders perusahaandengan menggunakan media komunikasi berbasis teknologi internet sebagai sarana publisitasnya.

Rusdianto dalam bukunya yang berjudul Cyber CSR: A Guide to CSR Communications on Cyber Media (2014: 76-77) menjelaskan bahwa Website dapat dilihat dari jenis dan kepemilikannya. Dilihat dari Jenisnya Website dibedakan menjadi dua jenis, yaitu Website statis dan Website dinamis. Website statis merupakan salah satu bentuk Website yang memiliki konten informasi tidak untuk di update secara berkala, sedangkan Website dinamis merupakan website yang memiliki informasi untuk di update secara berkala. Dilihat dari kepemilikannya website dapat dibedakan menjadi dua jenis, yaitu official web (web resmi) merupakan web milik lembaga yang sah dan memiliki otoritas terhadap web bersangkutan. Unfficial web (web tidak resmi) merupakan web yang dimiliki dan dikelola secara personal.

Hidayat (2014: 87) menjelaskan bahwa official website dibangun oleh perusahaan dan disesuaikan dengan kebutuhan publikasi informasi perusahaan. Fungsi official website perusahaan secara umum untuk menyebarluaskan informasi dengan segera dan sebagai sarana untuk meningkatkan reputasi perusahaan, official perusahaan harus memanfaatkan official Website secara maksimal untuk menumbuhkan kekuatan baik internal maupun eksternal perusahaan. Official Website secara otomatis dampaknya cepat dirasakan dibandingkan dengan media konvensional. Dapat dipahami bahwa official Website menjadi bagian utama dari media komunikasi yang efektif untuk perusahaan, termasuk sebagai media komunikasi CSR perusahaan.

Penjelasan selanjutnya oleh Harmoni (2014) bahwa Website memungkinkan perusahaan mengkomunikasikan proses yang sedang berlangsung terkait dengan pelaksanaan CSR perusahaan tanpa perlu menunggu komunikasi periodik seperti annual report dan sustainability report. Perusahaan dapat menggunakan potensi komunikasi Website untuk memperlihatkan eksistensi dan kepeduliannya kepada para stakeholders.Du et al. dalam jurnalnya yang berjudul "Striving for Legitimacy Through Corporate Social Responsibility: Insights from Oil Companies" (2012: 416) menyatakan bahwa: 
"Corporate Websites have been increasingly recognized as an important and mainstream CSR reporting tool because they can provide in-depth and comprehensive information about companies's CSR practices and also allow for strategic stakeholder communication".

Pernyataan diatas menjelaskan bahwa website perusahaan semakin diakui sebagai alat komunikasi CSR yang paling penting dan utama, karena perusahaan dapat memberikan informasi secara mendalam dan komprehensif terkait pelaksanaan CSR perusahaan dan website memungkinkan menjadi komunikasi strategis perusahaan bagi para stakeholders.

\section{Kerangka Media Richness Theory}

Harmoni (2014) website adalah media komunikasi yang lebih "kaya" dibandingkan dengan media tercetak yang konvensional. Hal ini didasari dengan potensi website yang dilihat dari Media Richness Theory. Kerangka Media Richness Theory (MRT), teori yang digunakan untuk melihat "kekayaan media", website merupakan media yang dapat memfasilitasi kebutuhan untuk mengkomunikasikan CSR. Penggunaan fitur website yang dikonseptualisasikan dengan menggunakan kerangka media richness, dalam praktiknya akan sejalan dengan kebutuhan manajemen untuk berkomunikasi melalui website.

Lodhia dalam jurnalnya yang berjudul "The World Wide Web and Its Potential for Corporate Environmental Communication: A Study into Present Practices in the Australian Minerals Industry" (2006: 69) menjelaskan bahwa Website memberikan informasi yang tepat waktu dan memungkinkan peningkatan aksesibilitas serta interaktivitas dengan berbagai stakeholders, selain membantu dalam presentasi dan informasi perusahaan. Namun, potensi Website belum secara ekstensif digunakan oleh perusahaan sebagai media komunikasi CSR. Website masih dianggap sebagai jembatan antara perusahaan dan publik. Meskipun demikian banyak yang sependapat bahwa Website akan menjadi media komunikasi CSR yang sangat penting.

\section{Kebutuhan Komunikasi Cyber CSR}

\begin{tabular}{|c|c|c|c|}
\hline $\begin{array}{l}\text { Kebutuhan } \\
\text { Komunikasi } \\
\text { CSR }\end{array}$ & Fitur Website & Pengertian & Kriteria \\
\hline $\begin{array}{l}\text { Ketepatan } \\
\text { waktu }\end{array}$ & Kesegaran & $\begin{array}{l}\text { Kesegeraan merujuk } \\
\text { pada kemampuan } \\
\text { media untuk } \\
\text { menyediakan } \\
\text { informasi } \\
\text { secaraberkala dan } \\
\text { memungkinkan } \\
\text { umpan balik secara } \\
\text { cepat. }\end{array}$ & $\begin{array}{ll}\text { a. } & \text { Perusahaan harus menunjukkan } \\
\text { kapan informasi CSR pada } \\
\text { halaman Website diperbarui. } \\
\text { b. Memastikan apakah perusahaan } \\
\text { memberikan indikasi tentang } \\
\text { penempatan informasi CSR yang } \\
\text { baru pada halaman Website. } \\
\text { c. Menentukan apakah perusahaan } \\
\text { menggunakan teknik seperti } \\
\text { webcast untuk isu-isu CSR } \\
\text { perusahaan. Webcast adalah } \\
\text { siaran langsung dari suatu } \\
\text { peristiwa melalui media Internet. }\end{array}$ \\
\hline Aksesibilitas & $\begin{array}{l}\text { Keragaman } \\
\text { Penerima }\end{array}$ & $\begin{array}{l}\text { Kemampuan Website } \\
\text { untuk berkomunikasi }\end{array}$ & $\begin{array}{l}\text { a. Memastikan apakah Website dapat } \\
\text { diakses oleh seluruh stakeholders } \\
\text { dan akses tidak boleh dibatasi }\end{array}$ \\
\hline
\end{tabular}


Diterbitkan oleh Program Studi IImu Komunikasi

Universitas Ahmad Dahlan Yogyakarta

\begin{tabular}{|c|c|c|c|}
\hline & & $\begin{array}{l}\text { dan menyampaikan } \\
\text { informasi CSR ke } \\
\text { berbagai } \\
\text { stakeholders. Dalam } \\
\text { hal ini Website } \\
\text { memiliki potensi } \\
\text { sebagai komunikasi } \\
\text { massa yang } \\
\text { menjangkau } \\
\text { penerima pesan } \\
\text { secara global. }\end{array}$ & $\begin{array}{l}\text { dengan password atau mekanisme } \\
\text { lain. } \\
\text { b. Di halaman Website apakah } \\
\text { menggunakan email alerts untuk } \\
\text { menargetkan berbagai } \\
\text { stakeholders. }\end{array}$ \\
\hline \multirow[t]{4}{*}{$\begin{array}{l}\text { Presentasi } \\
\text { dan } \\
\text { Organisasi }\end{array}$} & $\begin{array}{l}\text { Keragaman } \\
\text { Isyarat }\end{array}$ & $\begin{array}{l}\text { Keragaman isyarat } \\
\text { mengacu pada } \\
\text { kemampuan untuk } \\
\text { mengomunikasikan } \\
\text { pesan melalui } \\
\text { pendekatan yang } \\
\text { berbeda beda, } \\
\text { seperti tubuh, } \\
\text { bahasa, suara dan } \\
\text { intonasi. }\end{array}$ & $\begin{array}{l}\text { Di halaman Website apakah } \\
\text { perusahaan menggunakan alat } \\
\text { seperti grafis, animasi dan multimedia } \\
\text { (audio dan video klip) yang } \\
\text { dimanfaatkan untuk meningkatkan } \\
\text { presentasi Website. }\end{array}$ \\
\hline & $\begin{array}{l}\text { Keragaman } \\
\text { Bahasa }\end{array}$ & $\begin{array}{l}\text { Variasi bahasa } \\
\text { menunjukkan } \\
\text { kemampuan } \\
\text { penggunaan kata } \\
\text { yang berbeda untuk } \\
\text { meningkatkan } \\
\text { pemahaman, yaitu } \\
\text { pada variasi cara } \\
\text { dalam } \\
\text { menyampaikan ide } \\
\text { dan konsep melalui } \\
\text { simbol bahasa. }\end{array}$ & $\begin{array}{l}\text { a. Memastikan apakah perusahaan } \\
\text { memfasilitasi stakeholders pada } \\
\text { Website perusahaan dengan } \\
\text { menggunakan hyperlink, serta } \\
\text { menu dan format yang berbeda } \\
\text { untuk laporan. Hyperlink dibagi } \\
\text { menjadi internal (dalam sebuah } \\
\text { halaman web) dan eksternal (ke } \\
\text { Website lain). Hyperlink digunakan } \\
\text { untuk mengintegrasikan informasi } \\
\text { penting. } \\
\text { be } \\
\text { menastikan apakah perusahaan } \\
\text { mencakup Portable Document } \\
\text { Format (PDF), Hypertext Markup } \\
\text { Language (HTML) atau beberapa } \\
\text { yang lain format file. Serta } \\
\text { memastikan apakah laporan } \\
\text { disediakan dalam bahasa yang } \\
\text { berbeda. }\end{array}$ \\
\hline & $\begin{array}{l}\text { Sumber } \\
\text { Personal }\end{array}$ & $\begin{array}{l}\text { Sumber personal } \\
\text { memfokuskan pada } \\
\text { kemampuan untuk } \\
\text { menunjukkan } \\
\text { perasaan dan emosi. }\end{array}$ & $\begin{array}{l}\text { Memastikan apakah perusahaan } \\
\text { menggunakan hyperlink dan email } \\
\text { alerts untuk memberikan informasi } \\
\text { secara spesifik disesuaikan dengan } \\
\text { stakeholders. }\end{array}$ \\
\hline & $\begin{array}{l}\text { Memori } \\
\text { Terolahkan } \\
\text { Komputer }\end{array}$ & $\begin{array}{l}\text { Memori terolahkan } \\
\text { komputer berarti } \\
\text { bahwa informasi } \\
\text { dapat diorganisir dan } \\
\text { diatur secara } \\
\text { elektronik, misalnya }\end{array}$ & $\begin{array}{l}\text { a. Tersedia alat-alat untuk membantu } \\
\text { navigasi Website seperti search } \\
\text { engine, sitemaps, dan menu based } \\
\text { contents list. } \\
\text { b. Tersedia alat-alat analisis yang } \\
\text { dapat digunakan stakeholders }\end{array}$ \\
\hline
\end{tabular}




\begin{tabular}{|c|c|c|c|}
\hline & & $\begin{array}{l}\text { dapat diperoleh } \\
\text { melalui proses } \\
\text { pencarian. }\end{array}$ & $\begin{array}{l}\text { untuk memanipulasi informasi } \\
\text { berdasarkan kebutuhan mereka. }\end{array}$ \\
\hline & $\begin{array}{l}\text { Perekaman } \\
\text { Eksternal }\end{array}$ & $\begin{array}{l}\text { Kriteria perekaman } \\
\text { eksternal } \\
\text { berhubungan dengan } \\
\text { kemampuan media } \\
\text { untuk menyediakan } \\
\text { rekaman komunikasi, } \\
\text { termasuk } \\
\text { kemampuan untuk } \\
\text { mendokumentasikan } \\
\text { (juga memodifikasi) } \\
\text { proses komunikasi. }\end{array}$ & $\begin{array}{l}\text { a. Halaman Website menggunakan } \\
\text { fasilitas seperti hit counter dan } \\
\text { electronic guestbook untuk } \\
\text { melacak berapa banyak pihak yang } \\
\text { mengakses informasi CSR. } \\
\text { b. Menyediakan informasi CSR, } \\
\text { seperti laporan keberlanjutan dan } \\
\text { laporan tahunan untuk beberapa } \\
\text { tahun. } \\
\text { c. Adanya fasilitas agar stakeholder } \\
\text { dapat men-download dan mencetak } \\
\text { informasi CSR. }\end{array}$ \\
\hline Interaksi & Konkurensi & $\begin{array}{l}\text { konkurensi merujuk } \\
\text { pada kemampuan } \\
\text { media untuk } \\
\text { memfasilitasi } \\
\text { interaksi antara } \\
\text { banyak pengguna } \\
\text { secara simultan. }\end{array}$ & $\begin{array}{l}\text { Dalam halaman Website terdapat } \\
\text { fasilitas interaksi melalui email, forum } \\
\text { diskusi, bulletin boards, chatroom } \\
\text { atau dengan bentuk automatic } \\
\text { feedback forms dan electronic } \\
\text { surveys. }\end{array}$ \\
\hline
\end{tabular}

Sumber: Lodhia (2006:69-78) 
Diterbitkan oleh Program Studi IImu Komunikasi

Universitas Ahmad Dahlan Yogyakarta

\section{Kerangka Alur Pemikiran}

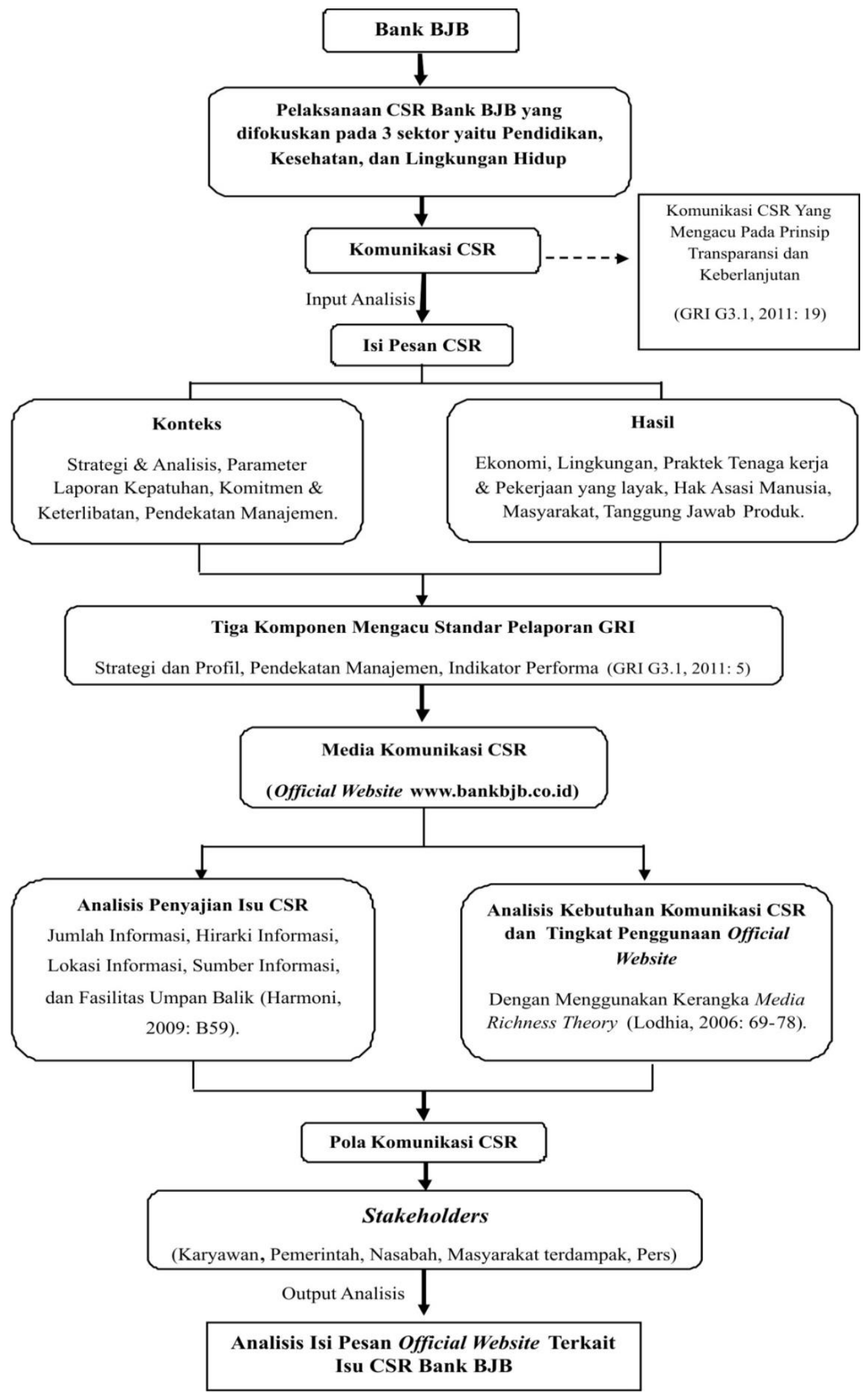




\section{Paradigma dan Metodologis}

\section{Asumsi Dasar Paradigma}

Dalam Jurnal ini, paradigma yang digunakan adalah paradigma konstruktivisme. Peneliti meninjau perspektif tersebut karena sesuai dengan penelitian yang dilaksanakan, yaitu upaya memaknai realitas sosial dalam konteks komunikasi cyber CSR, yang dilakukan oleh Bank BJB melalui official website dengan menggunakan interpretasi secara subjektif oleh peneliti.Konteks utama dalam penelitian ini terkait bagaimana isi pesan CSR yang dikomunikasikan oleh perusahaan kepada stakeholders, bagaimana perusahaan menyajikan informasi CSR pada official website, dan bagaimana pola komunikasi dalam media komunikasi offcial website yang digunakan oleh perusahaan yang akan membawa dampak pada reputasi perusahaan.

Secara khusus paradigma konstruktivisme berada dalam perspektif interpretivisme (penafsiran). Sebagaimana dijelaskan dalam proses sosial, individu manusia dipandang sebagai pencipta realitas sosial yang relatif bebas di dalam dunia sosialnya. Realitas sosial itu memiliki makna manakala realitas sosial tersebut dikonstruksikan dan dimaknakan secara subjektif oleh individu lain, sehingga memantapkan realitas itu secara objektif. Tujuan penelitian ini adalah mengkonstruksi realitas sosial secara dialektis antara peneliti dengan yang diteliti.

Denzin dan Lincoln (2009: 123) menjelaskan bahwa suatu paradigma memiliki asumsi-asumsi paradigma, meliputi tiga elemen yaitu: asumsi epistemologi (asumsi tentang relasi antara peneliti dan yang diteliti), asumsi ontologi (asumsi tentang realitas), dan asumsi metodologi (asumsi tentang cara/proses peneliti memperoleh pengetahuan).

Asumsi yang berbeda dari masing-masing paradigma tidak dapat dipandang semata-mata sebagai perbedaan filosofi, secara eksplisit maupun implisit, berbagai kondisi ini menimbulkan konsekuensi penting terhadap pelaksanaan praktis penelitian, demikian pula terhadap interpretasi temuan penelitian dan kebijakan yang dipilih. Persoalan etika merupakan konsekuensi yang muncul dalam pelaksanaan penelitian, dan isu-isu yang dipandang secara serius terutama dalam paradigma konstruktivisme (Denzin dan Lincoln, 2009: 139).

\section{Asumsi Filosofi Paradigma Konstruktivisme}

\begin{tabular}{|l|l|}
\hline Asumsi & Konstruktivisme \\
\hline Ontologi & $\begin{array}{l}\text { Mengenal relativisme, yakni realitas sosial yang akan diteliti merupakan realitas } \\
\text { adanya komunikasi cyber CSR yang dilakukan oleh Bank BJB pada official } \\
\text { Website. Peneliti mengkonstruksi realitas yang ada terkait isi pesan CSR, bentuk } \\
\text { penyajian informasi CSR, dan pola komunikasi CSR melalui konten-konten } \\
\text { pemberitaan, informasi CSR, dokumen yang diunggah, desain Website, } \\
\text { presentasi Website, dan fitur-fitur Website yang terdapat dalam official Website } \\
\text { tersebut. }\end{array}$ \\
\end{tabular}


Diterbitkan oleh Program Studi IImu Komunikasi

Universitas Ahmad Dahlan Yogyakarta

\begin{tabular}{|l|l|}
\hline Epistemologi & $\begin{array}{l}\text { Penelitian bersifat transaksional, yakni pemahaman atau temuan suatu realitas } \\
\text { yang terdapat pada official Website bank bjb merupakan hasil dari penalaran } \\
\text { peneliti secara subjektif dan sebagai hasil kreatif peneliti dalam membentuk } \\
\text { realitas. Hasil penelitian tercipta sebagaimana aslinya yaitu dari pesan-pesan } \\
\text { terkait isu CSR perusahaan yang Bank BJB tampilkan ke publik melalui official } \\
\text { Website selama proses penelitian berlangsung. }\end{array}$ \\
\hline Ethic & $\begin{array}{l}\text { Intrinsik, yakni peneliti cenderung melakukan penyingkapan dan pengembangan } \\
\text { konstruksi dengan memahami harapan-harapan yang diinginkan oleh Bank BJB } \\
\text { dalam komunikasi cyber CSR yang telah dilakukan melalui official Website. }\end{array}$ \\
\hline Metodologi & $\begin{array}{l}\text { Penelitian bersifat konstruktif, yakni peneliti melakukan konstruksi tanpa } \\
\text { dipengaruhi unsur manapun. Konstruksi diinterpretasikan sesuai dengan data } \\
\text { yang ada dan ditemukan pada official Website Bank BJB selama proses } \\
\text { penelitian berlangsung yang disesuaikan dengan landasan teori yang peneliti } \\
\text { gunakan. Penelitian juga dilakukan secara dialektis antara peneliti dengan yang } \\
\text { diteliti agar mendapatkan konstruksi yang lebih matang. }\end{array}$ \\
\hline
\end{tabular}
Adaptasi Dedi N. Hidayat, 2009

\section{Metode Analisis Isi Cyber CSR}

Analisis isi ini digunakan untuk melihat kecenderungan isi teks, yang memuat pesan terkait isu-isu CSR yang diinterpretasikan secara subjektif oleh peneliti pada official website Bank BJB melalui berita-berita CSR yang ditampilkan oleh perusahaan. Selain itu, peneliti akan menganalisis isi official website Bank BJB mengenai bentuk penyajian informasi CSR yang ditampilkan, dan pola komunikasi CSR antara perusahaan dan stakeholders.

Analisis isi dalam penelitian ini tidak dimaksudkan untuk menguji hipotesis tertentu, atau menguji hubungan antar variabel. Terkait dengan pendekatan yang peneliti gunakan Eriyanto (2011: 47) menjelaskan bahwa analisis isi dimaksudkan untuk menggambarkan secara detail suatu pesan, atau suatu teks tertentu.

Analisis isi semata dimaksudkan untuk deskripsi, menggambarkan aspek-aspek dan karakteristik isi media komunikasi terutama isi suatu pesan. Adapun Krippendroff (2004: 18) mendefinisikan analisis isi sebagai "a research technique for making replicable and valid inferences from texts (or other meaningfull matter) to the contexts of their use." Definisi tersebut diartikan sebagai teknik penelitian yang dapat ditiru dan sahih untuk membuat inferensi-inferensi dari teks pada pernyataan yang kaya akan makna lain dari konteks penggunaannya.

Dalam penelitian ini, peneliti melakukan analisis isi pesan CSR dengan menganalisis teks pada official website Bank BJB yang memuat informasi CSR dan teks yang sesuai dengan tujuan penelitian. Peneliti juga melakukan analisis secara longitudinal terhadap penyajian informasi CSR pada official website Bank BJB. Selanjutnya, peneliti melakukan analisis pola komunikasi CSR berdasarkan hasil analisis isi pesan CSR pada official website dan penyajian informasi CSR pada official website yang berkaitan dengan alur informasi CSR Bank BJB pada official website. 


\section{ANALISIS ISU KOMUNIKASI CYBER CSR}

\section{Informasi CSR Bank BJB Pada Official Website}

Berdasarkan hasil analisis penyajian isu CSR pada official website, peneliti melihat bahwa Bank BJB telah berupaya menyampaikan beberapa isu terkait CSR tetapi hanya menyajikan menu informasi terkait tata kelola perusahaan, ekonomi dan lingkungan, ketenagakerjaan, dan tanggung jawab produk. Hal tersebut menunjukkan bahwa jumlah informasi yang tersedia pada official website Bank BJB masih kurang optimal dalam memenuhi tuntutan publik dalam kebutuhan informasi terkait isu-isu CSR. Berikut hasil analisis penyajian informasi CSR pada official website Bank BJB berdasarkan konsep analisis penyajian informasi menurut Capriotti dan Moreno (2007: 227).

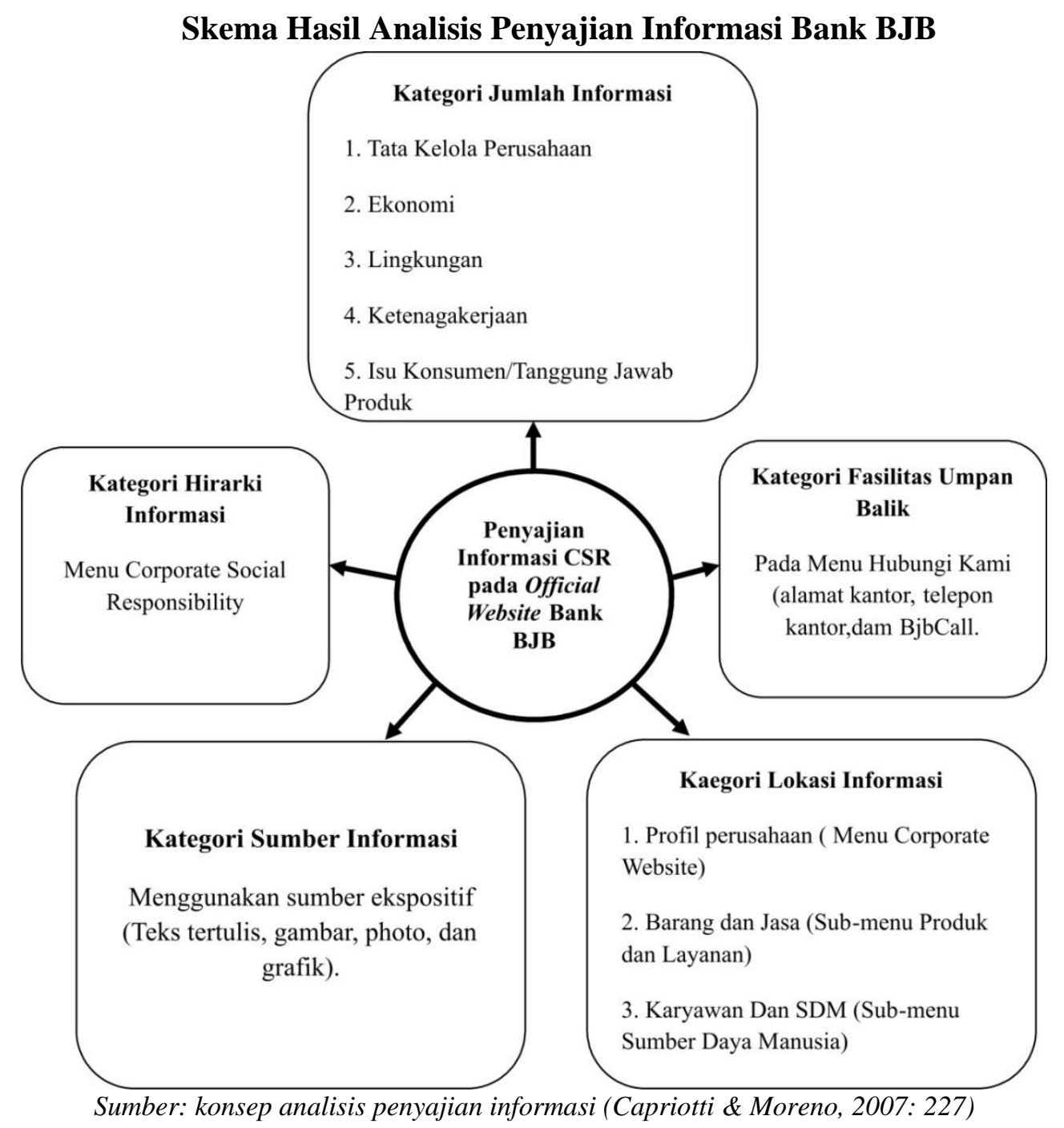

Kategori hirarki informasi CSR ditampilkan oleh perusahaan pada menu/kanal Corporate Social Responsibility dan mayoritas informasi terkait program CSR yang telah dilaksanakan dipublikasi pada sub menu "Berita". Bank BJB juga menampilkan informasi 
Diterbitkan oleh Program Studi IImu Komunikasi

Universitas Ahmad Dahlan Yogyakarta

terkait isu-isu CSR tetapi belum terlokalisasi secara menyeluruh pada menu tersendiri dalam official website.

Hasil analisis peneliti juga menunjukkan bahwa penyajian informasi yang dilakukan oleh Bank BJB pada official Website tidak dirancang secara efektif dan kelebihan yang dimiliki official website tidak dimanfaatkan oleh perusahaan untuk mengoptimalkan media komunikasi CSR yang lain. Seperti yang dapat dilihat bahwa pada official website Bank BJB menggunakan sumber informasi ekspositif berupa teks, gambar, photo, dan grafik saja. Sumber informasi ekspositif menunjukkan bahwa official website masih bersifat satu arah (undirectional).

Official website perusahaan dapat dikatakan masih sangat rendah tingkat interaktivitasnya, perusahaan hanya menitikberatkan pada publikasi informasi CSR dan tidak menyediakan sarana umpan balik yang membangun interaksi dan dialog antara perusahaan dengan berbagai stakeholders yang sifatnya beragam.

\section{Skema Analisis Tingkat Penggunaan Official Website Bank BJB}

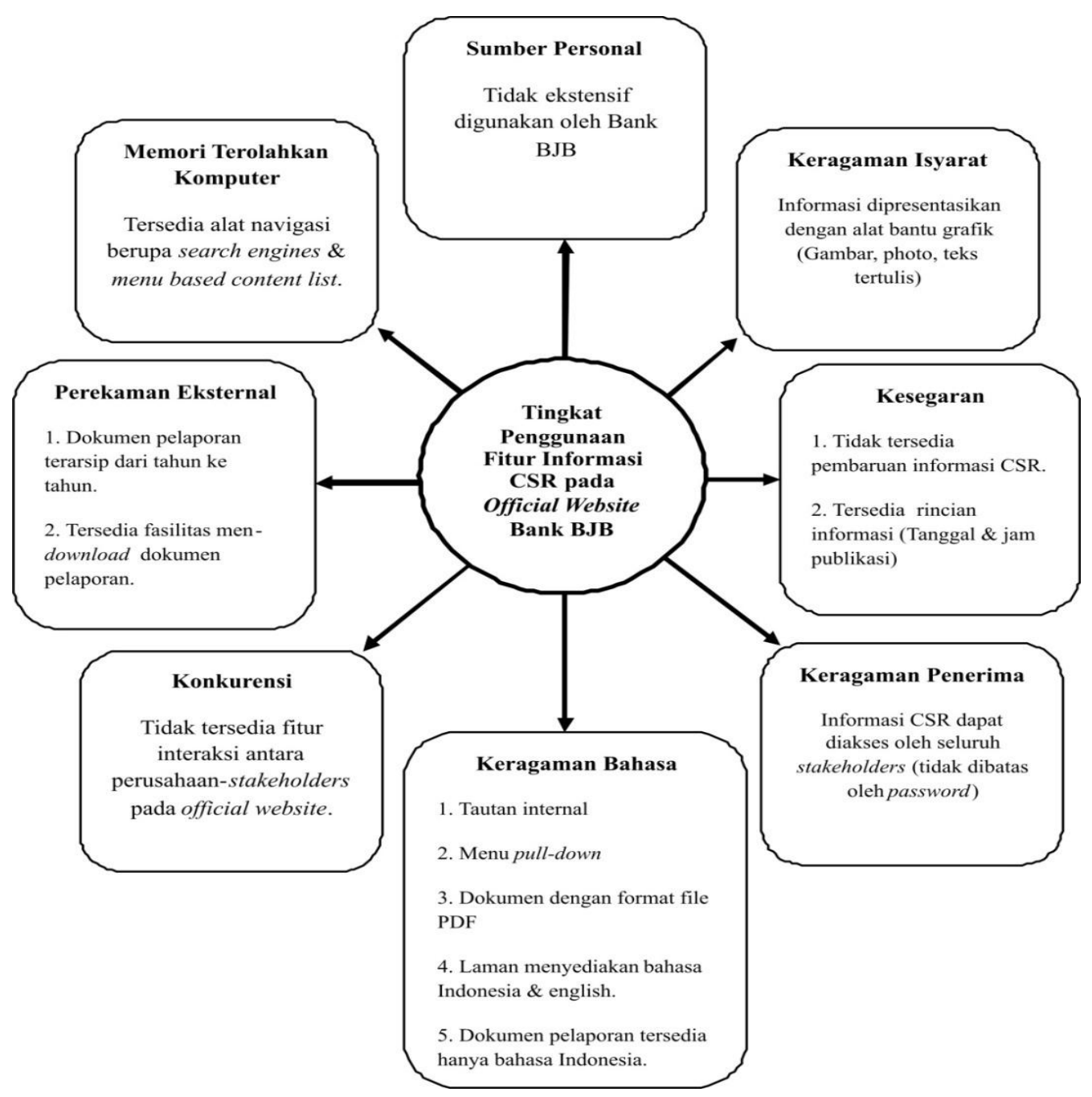

Sumber: Konsep Media Richness Theory (Lodhia, 2006: 69-78) 
Hasil analisis tingkat penggunaan fitur official website bahwa menunjukkan Bank BJB tidak sepenuhnya memanfaatkan potensi official website secara ekstensif untuk komunikasi CSR kepada stakeholders. Selaras dengan apa yang diungkapkan Lodhia (2006: 69) bahwa komunikasi CSR melalui web mulai banyak digunakan sebagai pelengkap komunikasi melalui media tercetak namun seluruh potensi web tidak dimanfaatkan oleh perusahaan untuk media komunikasi lingkungan.

Dalam melakukan analisis tingkat kebutuhan komunikasi CSR/tingkat penggunaaan official website peneliti melakukan pengamatan secara longitudinal untuk melihat dinamika perubahan pada official website. Peneliti melihat bahwa fitur kesegaran pada official website Bank BJB tidak dimanfaatkan untuk menyediakan informasi secara berkala dan memungkinkan umpan balik secara cepat. Hasil temuan data menunjukkan bahwa tidak adanya ketersediaan laporan terbaru atau rilis berita yang baru pada official website, upaya perusahaan untuk melakukan pembaruan berita CSR yaitu pada tanggal 11 April 2014.

Untuk fitur keragaman penerima, Bank BJB tidak membatasi official website untuk stakeholders tertentu, semua pengunjung baik pihak internal perusahaan maupun pihak eksternal dapat melakukan akses informasi terkait isu-isu CSR dan informasi perusahaan pada official Website. Dampak official Website sebagai media yang kaya dapat dikatakan tidak sepenuhnya mempengaruhi perusahaan untuk membangun presentasi yang baik terkait informasi CSR dengan alat presentasi berupa animasi maupun multimedia.

Selanjutnya terkait fitur keragaman bahasa, peneliti melihat bahwa official Website Bank BJB telah dimanfaatkan untuk mengorganisasikan informasi CSR kepada berbagai stakeholders menggunakan fitur keragaman bahasa secara ekstensif, namun perusahaan mengembangkan secara optimal yaitu terkait penggunaan tautan eksternal untuk memberikan informasi yang lebih mendalam sesuai dengan kebutuhan informasi stakeholders yang sifatnya beragam.

Untuk fitur sumber personal, hasil temuan data menunjukkan bahwa adanya integrasi menu dalam tiga kategori sebagai upaya perusahaan untuk memberi ruang informasi yang berbeda, namun peneliti melihat untuk menu "Corporate Website" dan menu "Investor Relation" memiliki kesamaan informasi, dapat dipahami bahwa official Website Bank BJB tidak ekstensif menggunakan fitur sumber personal, dapat dikatakan menu-menu yang ditampilkan pada official website terkesan kurang spesifik diperuntukkan bagi masalah atau informasi tertentu.

Pada official website seluruh stakheolders dapat menjangkau dan memperoleh informasi dengan mengunduh informasi dalam bentuk laporan tahunan/ keberlanjutan/GCG. Namun, berdasarkan hasil temuan data bahwa perusahaan tidak menggunakan fitur perekaman eksternal yang memiliki keuntungan untuk mengetahui jumlah pengunjung yang mengakses dan mengunggah informasi CSR. Tersedianya fasilitas hit counter dan guest book memungkinkan bagi perusahaan sebagai alat evaluasi untuk menilai performa Website yang dirancang agar menjadi media komunikasi cyber CSR yang lebih optimal kedepannya.

Dari sisi interaktivitas, hasil temuan data menunjukkan bahwa Bank BJB tidak menggunakan fitur konkurensi untuk memfasilitasi interaksi antara perusahaan dengan para stakeholders pada official website secara simultan. Stakeholders dapat berinteraksi 
Diterbitkan oleh Program Studi IImu Komunikasi

Universitas Ahmad Dahlan Yogyakarta

melalui nomor telepon kantor, namun interaksi tidak ditujukan secara langsung kepada Corporate Secretary dan Grup CSR Bank BJB. Dapat dikatakan bahwa interakstivitas isu CSR pada official website masing sangat rendah. Inti dari CSR adalah mengelola komunikasi CSR antara perusahaan dengan stakeholders.

Secara keseluruhan, walaupun Bank BJB mengklaim akan penting mengkomunikasikan terkait isu-isu CSR dan telah mengalokasikan menu tersendiri pada official website namun hal tersebut tidak mempengaruhi informasi CSR yang dikomunikasikan mengacu pada prinsip transparansi dan konsistensi. Hal ini dikarenakan bahwa perusahaan telah mengalokasikan menu CSR pada hirarki yang tinggi pada official website namun mempunyai tingkat interaktivitas yang sangat rendah dan keterbatasan informasi yang dikomunikasikan oleh perusahaan.

\section{Pola Komunikasi CSR Bank BJB Pada Official Website}

Dalam program CSR setiap perusahaan harus memperhatikan aspek-aspek perancangan pesan CSR yang akan dikomunikasikan kepada stakeholders, serta perusahaan dituntut untuk memilih media yang akan digunakan dan bagaimana cara mengelola media tersebut. Komunikasi CSR yang dilakukan oleh perusahaan bertujuan untuk membangun dan menjaga reputasi di mata para stakeholders.

Dapat dipahami bahwa pada media komunikasi official website, Bank BJB tidak berupaya membangun kepercayaan dengan mendengarkan harapan dari stakeholders terhadap informasi yang dikomunikasikan perusahaan terkait performa. Sebagaimana dengan apa yang diungkapkan oleh Harmoni (2009: B58) bahwa untuk mendapatkan legitimasi dari para stakeholders, perusahaan dituntut agar membangun komunikasi CSR dengan melibatkan para stakeholders yakni mendengarkan apa yang diharapkan oleh mereka terhadap pelaksanaan CSR yang dilakukan.

Seperti yang telah dipaparkan pada analisis penyajian informasi CSR, menunjukkan bahwa official website Bank BJB tergolong sangat rendah tingkat interaktivitasnya, hal ini karena penggunaan official website Bank BJB masih tergolong satu arah (oneasymmetrical). Peneliti melihat bahwa perusahaan lebih menitikberatkan hanya pada publikasi informasi semata dan tidak menyediakan fasilitas umpan balik yang memadai sebagai media interaksi dan membangun dialog ke berbagai stakeholders yang berbeda.

Dapat dipahami bahwa Bank BJB tidak mendengar dan mempertimbangkan suara stakeholders terhadap pesan CSR yang dikomunikasikan, namun lebih memaparkan kebijakan berdasarkan kemauan perusahaan. Oleh karena itu komunikasi cyber CSR yang dilakukan oleh Bank BJB tidak menunjukkan sebagaimana definisi komunikasi cyber CSR dipahami. Selaras dengan apa yang diungkapkan oleh Rusdianto (2014: 102) bahwa dalam pelaksanaan CSR perusahaan tidak hanya berdasarkan apa yang diinginkan oleh perusahaan, tetapi mendengarkan apa yang diharapkan oleh stakeholders melalui komunikasi CSR yang transparan.

Berdasarkan isi berita CSR yang telah peneliti analisis menunjukkan bahwa informasi yang ditampilkan tidak adanya pengaruh dari suara stakeholders maupun pihak kritis. Tidak adanya upaya perusahaan memanfaatkan media official website untuk membangun saling pengertian, dukungan, dan menguntungkan bagi kedua belah pihak baik 
perusahaan maupun stakeholders. Pola komunikasi CSR yang terbangun melalui official website Bank BJB merupakan proses komunikasi satu arah (one asymmetrical communication) sebagaimana perusahaan mendominasi official website. Bank BJB tidak berupaya mendesain official website secara optimal sebagai ruang stakeholders yang memiliki potensi interkativitas, sehingga informasi terkait isu-isu CSR tidak hanya bersumber dari satu pihak perusahaan semata.

Pada official website, Bank BJB tidak berupaya menyediakan fasilitas umpan balik bagi stakeholders sebagai ruang untuk memberikan masukan, kritik, dan verifikasi terkait informasi CSR yang ditampilkan oleh perusahaan pada official website, seperti email khusus yang dapat terhubung secara langsung dengan Corporate Secretary.

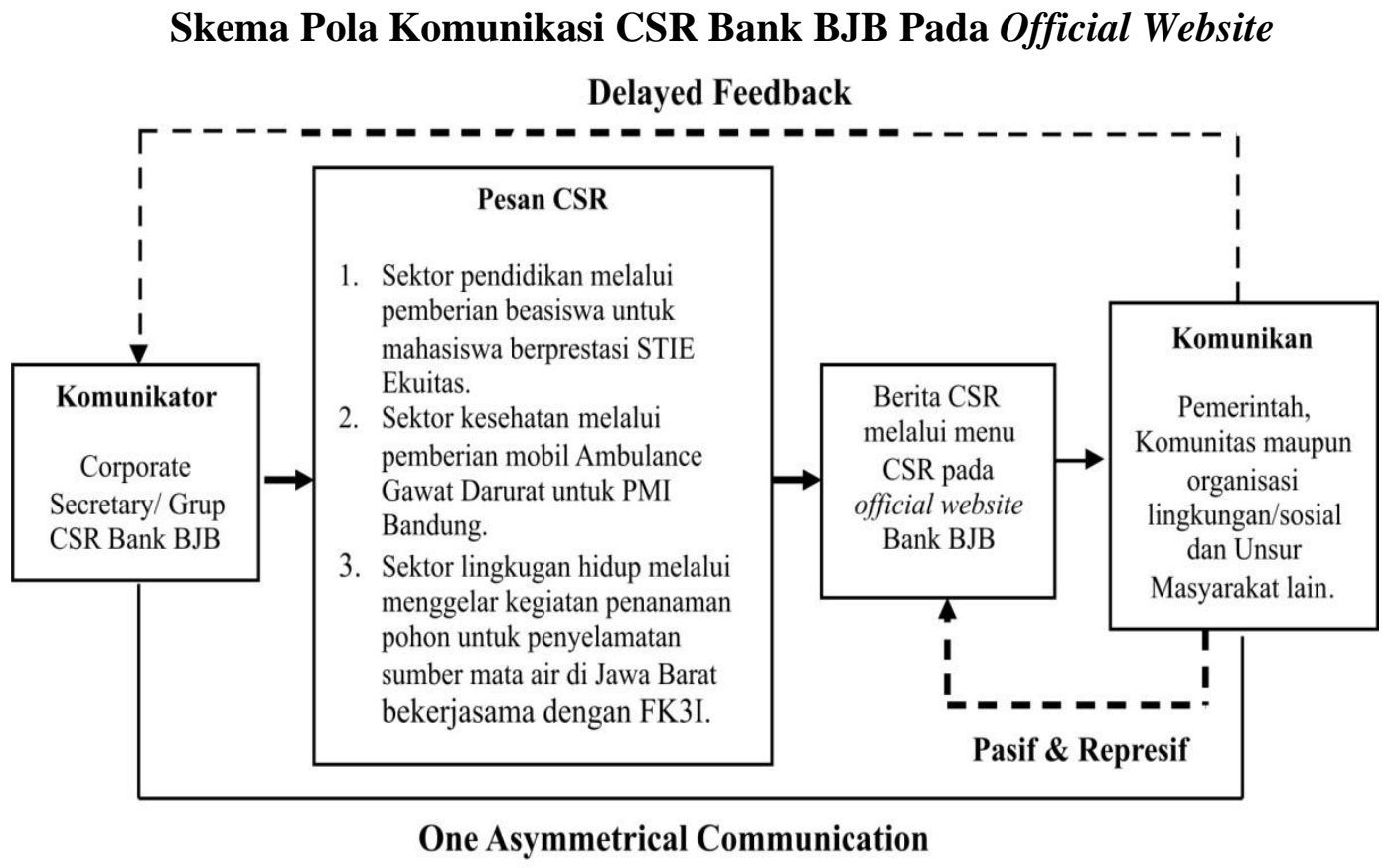

Peneliti melihat bahwa official website Bank BJB sebagai media komunikasi cyber CSR yang hegemoni, sebagaimana bertolak belakang dengan potensi komunikasi yang dimiliki official website sebagai media yang terdesentralisasi dan lebih demokratis dibandingkan media komunikasi CSR yang lainnya. Selaras dengan model komunikasi Grunig dan Hunt (Butterick, 2012: 30-34) yaitu model public information, model ini berupaya membangun kepercayaan perusahaan melalui proses komunikasi satu arah dan tidak mementingkan persuasif, seolah bertindak sebagai wartawan dalam publisitas informasi dan berita ke publik, unsur kebenaran dan obyektivitas diperhatikan.

Dengan demikian, peneliti melihat bahwa pola komunikasi CSR pada official website Bank BJB merupakan pola komunikasi yang menggunakan model public information dari model komunikasi Grunig dan Hunt dalam praktik PR. Perusahaan mengelola pesan dalam bentuk berita CSR yang dikomunikasikan kepada seluruh stakeholders melalui official website namun stakeholders hanya bersifat pasif dan represif 
Diterbitkan oleh Program Studi IImu Komunikasi

Universitas Ahmad Dahlan Yogyakarta

terhadap informasi CSR yang dikomunikasikan oleh perusahaan tanpa memberikan verifikasi, kritik, saran, serta penilaian performa sebagai umpan balik (feedback).

Pola komunikasi CSR dengan model public information menunjukkan bahwa official website Bank BJB bersifat one asymmetrical communication, perusahaan hanya bertujuan mensosialisasikan informasi CSR tanpa membangun dialog untuk pertukaran informasi antara perusahaan dengan para stakeholders. Selaras dengan apa yang diungkapkan oleh Grunig dan Hunt dalam Rusdianto (2014: 106) bahwa komunikasi model public information pada dasarnya dipandang sebagai "mengatakan" tidak "mendengarkan", oleh karena itu komunikasi satu arah (one asymmetrical communication) memiliki tujuan untuk mensosialisasikan informasi.

\section{E. Refleksi Komunikasi Cyber CSR BJB}

Dari hasil penelitian terkait isi pesan CSR, penelitian ini menunjukkan bahwa pesan CSR yang dikomunikasikan oleh Bank BJB pada official website tidak mengacu pada prinsip transparansi dan konsistensi. Informasi CSR yang dikomunikasikan oleh Bank BJB pada official Website menunjukkan bahwa perusahaan tidak mengkomunikasikan seluruh komponen dalam pesan CSR yang dianjurkan oleh standar Global Reporting Initiative.

Hasil temuan data menunjukkan bahwa indikator penting dalam pesan CSR yang harus dikomunikasikan kepada stakeholders meliputi pendekatan manajemen dan indikator performa tidak dikomunikasikan oleh perusahaan pada official Website. Dapat dikatakan bahwa Bank BJB terkesan tidak berupaya memberi fokus perhatian dalam memuat informasi CSR terkait aspek perancangan program CSR dan dampak operasi perusahaan terhadap kinerja ekonomi, kinerja sosial, dan kinerja lingkungan pada official website.

Selain itu, pada official website Bank BJB sekedar mengkomunikasikan keseluruhan informasi CSR dalam bentuk berita CSR, hasil analisis isi berita CSR yang dipublikasi pada official Website menunjukkan bahwa perusahaan cenderung mengkomunikasikan informasi terkait pelaksanaan program CSR meliputi rangkaian aktivitas, bantuan yang diinvestasikan, waktu pelaksanaan, jumlah bantuan, jenis bantuan, dan khalayak yang menerima bantuan. Peneliti menyimpulkan bahwa tidak adanya upaya Bank BJB mengarahkan stakeholders untuk memberikan penilaian yang baik terhadap performa pada official website yang dikelola.

Prinsip transparansi terkesan diabaikan dalam komunikasi cyber CSR yang telah dikelola Bank BJB dalam memperoleh legitimasi dan membangun reputasi perusahaan. Hal ini dikarenakan isi pesan CSR yang dikomunikasikan tidak memiliki keseimbangan antara kegiatan CSR yang telah dilaksanakan perusahaan dengan ketersediaan informasi CSR yang dikomunikasikan pada official website.

Hasil analisis menunjukkan bahwa official website Bank BJB sebagai media komunikasi cyber CSR memiliki kemampuan yang masih sangat rendah dalam menyajikan informasi CSR perusahaan. Hasil penelitian penyajian informasi CSR memperlihatkan upaya Bank BJB dengan mengalokasikan menu khusus CSR pada official website, namuntidak menunjukkan bahwa perusahaan telah memberikan fokus perhatian terhadap informasi CSR yang dikomunikasikan pada tingkat hirarki yang tinggi. 
Official website Bank BJB memiliki kemampuan akses yang rendah yakni bersifat non-user friendly, tidak interaktif, tidak menyediakan informasi CSR secara kompherensif, dan penggunaan sumber informasi pada official website merupakan sumber ekspositif berupa teks, gambar, photo, dan grafik dalam menyajikan informasi CSR.

Hasil analisis tingkat penggunaan fitur official website bahwa Bank BJB tidak sepenuhnya memanfaatkan potensi official Website secara ekstensif untuk komunikasi CSR kepada stakeholders. Hal ini dikarenakan perusahaan hanya mengatur informasi CSR melalui sumber personal, memori terolahkan komputer, dan keragaman penerima. Informasi yang tersedia pada official website dapat diakses oleh seluruh stakeholders dan publik lainnya, perusahaan juga memanfaatkan fitur navigasi berupa search engine dan menu based content list yang dapat mempermudah pencarian informasi CSR.

Kategori kesegaran, konkurensi, keragaman isyarat keragaman bahasa, dan perekaman eksternal merupakan fitur utama yang harus digunakan secara ektensif oleh perusahaan, namun tidak dimanfaatkan oleh Bank BJB dalam mengatur informasi CSR pada offcial website. Potensi yang dimiliki oleh website sebagai media komunikasi cyber CSR tidak dimanfaatkan sepenuhnya oleh Bank BJB dalam menyajikan informasi CSR secara optimal.

Dapat dipahami bahwa official website Bank BJB memiliki kemampuan yang sangat lemah sebagai media komunikasi cyber CSR, dimungkinkan hal tersebut dipengaruhi oleh faktor-faktor kontekstual yakni memungkinkan adanya isu keterbatasan akses pada sebagian pemangku kepentingan, isu kerahasiaan dan keamanan, kekhawatiran akan informasi yang berlebihan, hingga biaya yang diperlukan untuk mengelola official website.

Hasil penelitian menunjukkan bahwa pola komunikasi CSR Bank BJB pada official website merupakan bentuk komunikasi satu arah (one asymmetrical communication) sebagaimana ruang informasi CSR hanya diominasi oleh pihak Bank BJB. Pola komunikasi CSR pada official website Bank BJB merupakan pola komunikasi model public information dari model komunikasi Grunig dan Hunt dalam praktik PR.

Perusahaan mengelola pesan dalam bentuk berita CSR yang dikomunikasikan kepada seluruh stakeholders melalui official website, namun stakeholders hanya bersifat pasif dan represif terhadap informasi CSR yang dikomunikasikan oleh perusahaan tanpa memberikan verifikasi, kritik, saran, serta penilaian performa sebagai umpan balik (feedback).Pola komunikasi CSR dengan model public information menunjukkan bahwa official Website Bank BJB bersifat one asymmetrical communication, perusahaan hanya bertujuan mensosialisasikan informasi CSR tanpa membangun dialog untuk pertukaran informasi antara perusahaan dengan para stakeholders.

Dengan demikian, walaupun Bank BJB mengganggap penting terkait isu-isu CSR dan telah mengalokasikan menu tersendiri pada official website namun hal tersebut tidak mempengaruhi informasi CSR yang dikomunikasikan mengacu pada prinsip transparansi dan konsistensi. Bank BJB yang telah terdaftar pada Bursa Efek Indonesia dan tergabung dalam Asosiasi Emiten Indonesia, dapat dikatakan perusahaan telah berhasil mengelola reputasi yang baik di mata publik. Walaupun demikian, reputasi baik yang dimiliki oleh Bank BJB tidak dipengaruhi oleh komunikasi CSR yang dikelola perusahaan. 
Diterbitkan oleh Program Studi IImu Komunikasi

Universitas Ahmad Dahlan Yogyakarta

Peneliti menyimpulkan bahwa Bank BJB tidak membangun reputasi melalui komunikasi cyber CSR yang dikelola pada official website, reputasi perusahaan yang dibangun oleh Bank BJB terkesan dipengaruhi oleh faktor-faktor kontekstual sebagai perbankan daerah yang telah go public.

\section{Daftar Pustaka}

Ahmadi, Ruslam. (2014). Metodologi Penelitian Kualitatif. Yogyakarta: Ar-Ruzz Media. Ardial. (2014). Paradigma dan Model Penelitian komunikasi. Jakarta: Bumi Aksara.

Butterick, Keith. (2006). Pengantar Public Relations: Teori dan Praktek.Terj. Nurul Hasfi. Jakarta: Rajawali Pers.

Denzin, Norman K, dan Lincoln, Yvonna S. (2009). Handbook Of Qualitative Research. Terjemahan oleh Dariyatno, Badrus Samsul Fata, Abi, dan John Rinaldi. Yogyakarta: Pustaka Pelajar.

Daymon, Christine, dan Holloway, Immy. (2011). Qualitative Research Methods in Public Relations and Marketing Communications. Oxon: Routledge.

Emzir. (2014). Metodologi Penelitian Kualitatif: Analisis Data. Jakarta: PT Raja Grafindo Persada.

Eriyanto. (2004). Analisis Wacana, Pengantar Analisis Isi Media. Yogyakarta: LKIS. -. (2011). Analisis Isi: Pengantar Metodologi Untuk Penelitian Ilmu Komunikasi dan Ilmu-Ilmu Sosial Lainnya. Jakarta: Kencana.

Hidayat, Dasrun. (2014). Media Public Relations: Pendekatan Studi Kasus Cyber Public Relations Sebagai Metode Kerja PR Digital. Yogyakarta: Graha Ilmu.

Ikbar, Yanuar. (2012). Metode Penelitian Sosial. Bandung: PT Refika Aditama.

Krippendorff, Klaus. (2004). Content Anlaysis: An Introduction to Its Methodology.

Kriyantono, Rachmat. (2008). Teknik Praktis Riset Komunikasi: Disertai Contoh Praktis Riset Media, Public Relations, Advertising, Komunikasi Organisasi, Komunikasi Pemasaran. Jakarta: Kencana.

Nurjaman, Kadar dan Umam, Khaerul. (2012). Komunikasi Public Relation Panduan Untuk Mahasiswa, Birokrat, dan Praktis Bisnis. Bandung: CV Pustaka Setia.

Rachman, Nurdizal M, Efendi, Asep dan Wicaksana, Emir. (2011). Panduan Lengkap Perencanaan CSR. Jakarta: Penebar Swadaya.

Rusdianto, Ujang. (2013). CSR Communications: A Framework of PR Practicioner. Yogyakarta: Graha Ilmu. (2014). CYBER CSR: A Guide to CSR Communications on Cyber Media.Yogyakarta: Graha Ilmu 
